\title{
In vitro selection of autochthonous lactic acid bacterium from clownfish Amphiprion ocellaris
}

\author{
Peterson Emmanuel Guimarães Paixão ${ }^{1}$ (D) | Márcia Valéria Silva Couto ${ }^{2}$ | \\ Natalino Costa Sousa ${ }^{2}$ | Higo Andrade Abe ${ }^{2}$ (D) | Joel Artur Rodrigues Dias ${ }^{2}$ | \\ Juliana Oliveira Meneses ${ }^{1}$ | Fernanda Santos Cunha ${ }^{1}$ | José Luiz Pereira Mourino ${ }^{3}$ | \\ Maurício Laterça Martins ${ }^{3}$ | Rodrigo Yudi Fujimoto ${ }^{4}$ \\ ${ }^{1}$ Graduate Program in Health and Environmental, Tiradentes University (UNIT), Aracaju, Brazil \\ ${ }^{2}$ Graduate Program in Animal Science, Federal University of Pará (UFPA), Belém, Brazil \\ ${ }^{3}$ Aquaculture Department, AQUOS-Aquatic Organisms Health Laboratory, Federal University of Santa Catarina (UFSC), Florianopolis, Brazil \\ ${ }^{4}$ Brazilian Agricultural Research Corporation (EMBRAPA), Aracaju, Brazil
}

Correspondence

Rodrigo Yudi Fujimoto, Brazilian Agricultural Research Corporation (EMBRAPA), Av. Beira Mar 3250, 49025-040, Aracaju, Sergipe, Brazil. Email: ryfujim@hotmail.com

Funding information

National Council for Scientific and Technology development (CNPq), Grant/Award Number: 305195/2016-6, CNPq 306635/2018-6, CNPq 301524/2017-3 and $12 / 2016$

KEYWORDS: Anemonefish, clownfish, marine fish, ornamental

Ornamental aquaculture has been growing around the world as an important economic activity (FAO, 2017). However, its increase in production has promoted the outbreak of diseases due to high stocking densities and inadequate handlings in captivity (Pavanelli, Eiras, \& Takemoto, 2008). In this scenario, probiotics stand out as a sustainable alternative to antibiotics, which are commonly used for disease control. Probiotic is a live microorganism supplemented in the diet to promote benefits to the host (Sayes, Leyton, \& Riquelme, 2018). In recent years, various reports have been published about the use of autochthonous probiotics in aquaculture, such as Lactobacillus plantarum, Lactobacillus brevis, Lactobacillus acidophilus, Bacillus subtilis, Enterococcus faecium and Bacillus velezensis (Jatobá et al., 2018; Nandi et al., 2017; Sayes et al., 2018).

The first step to determine the probiotic potential is through in vitro tests (Vieira et al., 2013). The ability to colonize the intestinal tract is the main characteristic of probiotic bacteria (Balcázar et al., 2006). For this reason, specific in vitro tests, such as resistance to $\mathrm{pH}, \mathrm{NaCl}$ and bile salts, would aid in the selection for adequate probiotics (Vieira et al., 2013).

Nowadays, few papers have been published about the use of probiotics for clownfish (Wesseling et al., 2015), but there is no reports about the use of autochthonous bacteria as probiotics for Amphiprion ocellaris. Thus, the current study aimed to isolate and apply in vitro tests in autochthonous bacteria with probiotic potential to the clownfish A. ocellaris.
In the experiment, six fish were anesthetized (benzocaine solution $20 \mathrm{mg} / \mathrm{L}$ ) (Pramod, Sajeevan, Ramachandran, Thampy, \& Pai, 2010) and euthanized by medullar section according to animal ethics committee (CEUA Number 010218). Their intestinal tract was removed, macerated in sterile saline solution $(\mathrm{NaCl} 1.5 \%)$, serially diluted in a factor of 1:10 and inoculated on Petri dishes with De Man, Rogosa, and Sharpe agar (MRS agar) supplemented with $\mathrm{NaCl} 1.5 \%$ and aniline blue $1 \%$. Each plate was incubated for $48 \mathrm{hr}$ at $35^{\circ} \mathrm{C}$ to bacterial growth.

Colonies (coccus or bacillus) presenting gram-positive coloration, negative catalase and affinity for aniline blue were selected. To determine the growth kinetics, each selected colony was inoculated in MRS broth culture medium and incubated for $24 \mathrm{hr}$ at $35^{\circ} \mathrm{C}$, and growth evaluated each $2 \mathrm{hr}$ aided by spectrophotometer at absorbance of $630 \mathrm{~nm}$. At the same evaluation time, agar plates also inoculated and incubated to allow bacterial growth. The absorbance values were converted to colony-forming units (CFUs) through exponential regression, and the maximum growth rate and duplication time were determined (Ramirez et al., 2017).

For resistance tests, experiments were performed in a completely randomized design using different levels of $\mathrm{NaCl}(0,1.5,3.0$ and 4.5\%), $\mathrm{pH}(2.5,5.0,7.5$ and 9.0) and salt bile (5\% weight/volume) in triplicate. The reduction in percentage absorbance $(630 \mathrm{~nm})$ of colonies grown in MRS broth $\left(35^{\circ} \mathrm{C}\right.$ for $48 \mathrm{hr}$ ) was evaluated. 
Another test carried out was the antagonistic ability against pathogens such as Aeromonas hydrophila (CPQBA22808 DRM), Aeromonas jandaei (LAQUA), Vibrio fluvialis (LAQUA), Vibrio parahaemolyticus (LAQUA), Shewanella putrefaciens (LAQUA), Citrobacter freundii (LAQUA), Staphylococcus aureus (ATCC 29213), Enterococcus duran (ATCC19432) and Escherichia coli (D363).

For this test, each selected bacterium with probiotic potential was inoculated in MRS agar and incubated at $35^{\circ} \mathrm{C}$ for $48 \mathrm{hr}$. After bacterial growth, agar discs with a diameter of $0.8 \mathrm{~cm}$ were sectioned from these plates and allocated into other plates containing tryptone soya agar (TSA) inoculated with the pathogens. A positive control without probiotic bacteria containing an antibiotic (oxytetracycline $3 \mathrm{mg} / \mathrm{L}$ ) was used for comparison. After incubation $\left(35^{\circ} \mathrm{C}\right.$ at $48 \mathrm{hr}$ ), the inhibition halo ( $\mathrm{mm}$ ) against pathogens was determined.

In vitro results were submitted to the Kruskal-Wallis and post hoc Dunn non-parametric test $(p<.05)$. The best strain selected as a possible probiotic was identified by MALDI-TOF-MS (matrix-assisted laser desorption ionization time-of-flight mass spectrometry) using the molecular weight of ribosomal proteins with laser shots at a wavelength of $260-337 \mathrm{~nm}$. Scores $\geq 1.7$ were used to identify the genus and species (Tekippe, Shuey, Winkler, Butler, \& Burnham, 2013).

Eight lactic acid bacteria with different morphological aspects were isolated in MRS agar. Only five followed to in vitro tests due to gram-positive coloration, negative catalase activity and an affinity for blue aniline (ST01, ST02, ST03, ST04 and ST05). Two strains (ST01 and ST05) had the largest values $(p<.05)$ of maximum growth rate $(1.16 \pm 0.03$ and $1.16 \pm 0.01 \mathrm{a}$ cell $/ \mathrm{hr})$ and total viable cells $\left(14.11 \pm 7.54\right.$ and $\left.22.04 \pm 6.12 \mathrm{a} / \mathrm{ml} \times 10^{8} \mathrm{CFU}\right)$. In the resistance test, the highest growth observed was for ST03 in the presence of bile salt $(5 \% \mathrm{w} / \mathrm{v})$ followed by ST05 and ST01. The ST05 presented the highest resistance $(p<.05)$ to $\mathrm{NaCl}$ and $\mathrm{pH}$ alterations (Table 1 ), and the lowest resistance was observed to strains ST02 and ST04.

Regarding to antagonistic ability against pathogens, the ST05 showed the highest inhibition halo against Vibrio parahaemolyticus, Vibrio fluvialis, Aeromonas hydrophila, Aeromonas Jandaei, Escherichia coli, Citrobacter freundii and Shewanella putrefaciens (Table 2) being similar to the antibiotic. All other isolated strains (ST01, ST02, ST03 and ST04) showed similar or reduced performance when compared to the ST05. The bacterium with the best results for resistance tests and antagonistic ability was identified by MALDI-TOF-MS as Lactobacillus plantarum DSM 2360 (score of 2.01).
The lactic acid bacterium Lactobacillus plantarum has been used in recent years for aquaculture, reporting various benefits to the host (Jatobá et al., 2018; Van Doan, Doolgindachbaporn, \& Suksri, 2016). Its ability to quickly colonize the intestinal tract is the main characteristic (Jatobá et al., 2018). This specific ability could be related to the growth rate, which is a fundamental factor for probiotic bacteria (Vine et al., 2004). However, despite of fast growth it has low resistance in bile salt. According to Balcázar et al. (2008), Lactobacillus plantarum isolated from rainbow trout Oncorhynchus mykiss showed low viability in bile salt. This reduction was also observed in the present study. Bile salt works as a natural emulsifier making soluble fats and some vitamins, thereby acting as a bactericidal, breaking down the cellular wall of microorganisms (Lambert, Bongers, de Vos, \& Kleerebezem, 2008).

Resistance to $\mathrm{pH}$ is another important aspect from probiotic bacteria (Succi et al., 2005; Vieira et al., 2013). According to Son et al. (2017), Lactobacillus plantarum shows good growth in low pH levels. In the present study, $\mathrm{pH}$ resistance was observed to both acid $\mathrm{pH}$ (2.5) and alkaline $\mathrm{pH}$ (9.0) when compared to other isolated bacteria. This characteristic allows the probiotic bacteria be used in the diet of the host (Sayes et al., 2018).

Among the main water quality parameters, bacterial growth could be affected by different salinity levels (Vieira et al., 2013). For marine fish, due to the specific mechanism of osmoregulation, different salinity concentrations are observed in their intestinal tracts (Baldisserotto, Mancera Romero, \& Kapoor, 2007; Whittamore, 2012). Nonetheless, some lactic acid bacteria used as probiotics show resistance to different salinity levels (Ricciardi, Parente, \& Zotta, 2009; Vieira et al., 2013), for example L. plantarum. For these reasons, it shows resistance to factors such as stomach acidity, different salinity concentrations and bile enzyme activity that make colonization by a probiotic feasible. The bacteria colonizing the intestinal tract inhibit the pathogenic bacteria through the competition for nutrients and space (Jatobá et al., 2018; Sayes et al., 2018).

The ability to inhibit any pathogenic bacteria is the most important characteristic for a probiotic in aquaculture (Cornélio et al., 2013; Dias et al., 2018). In this scenario, lactic acid bacteria stand out due to the production of specific components with bactericidal potential (Balcázar et al., 2006). According to Vieira et al. (2013), Lactobacillus plantarum shows a good ability to inhibit the growth of pathogens such as Aeromonas hydrophila, Escherichia coli, Enterococcus duran, Vibrio

TABLE 1 Mean values of reduction resistance tests of different strains (in \%)

\begin{tabular}{llllllll} 
Strain & Salt Bile & $\mathrm{NaCl} 0 \%$ & $\mathrm{NaCl} 3 \%$ & $\mathrm{NaCl} 4.5 \%$ & $\mathrm{pH} 2.5$ & $\mathrm{pH} 5.0$ & $\mathrm{pH} 9.0$ \\
\hline ST01 & $21.07 \pm 1.69 \mathrm{abc}$ & $43.40 \pm 4.37 \mathrm{c}$ & $72.26 \pm 1.33 \mathrm{ab}$ & $66.72 \pm 1.36 \mathrm{a}$ & $65.15 \pm 2.12 \mathrm{ab}$ & $74.98 \pm 2.08 \mathrm{~b}$ & $94.74 \pm 2.09 \mathrm{ab}$ \\
\hline ST02 & $15.74 \pm 1.76 \mathrm{bc}$ & $54.36 \pm 2.52 \mathrm{ab}$ & $55.06 \pm 2.08 \mathrm{c}$ & $49.92 \pm 2.16 \mathrm{ab}$ & $56.57 \pm 7.04 \mathrm{~b}$ & $70.24 \pm 3.79 \mathrm{~b}$ & $88.82 \pm 8.32 \mathrm{~b}$ \\
\hline ST03 & $27.47 \pm 3.82 \mathrm{a}$ & $47.49 \pm 0.97 \mathrm{bc}$ & $60.54 \pm 2.77 \mathrm{abc}$ & $37.45 \pm 2.30 \mathrm{ab}$ & $41.36 \pm 5.01 \mathrm{c}$ & $92.56 \pm 1.92 \mathrm{a}$ & $91.41 \pm 4.77 \mathrm{ab}$ \\
\hline ST04 & $15.00 \pm 2.04 \mathrm{c}$ & $55.54 \pm 2.06 \mathrm{a}$ & $57.27 \pm 1.12 \mathrm{bc}$ & $29.97 \pm 0.88 \mathrm{~b}$ & $39.30 \pm 5.54 \mathrm{c}$ & $47.68 \pm 7.06 \mathrm{c}$ & $94.74 \pm 2.11 \mathrm{ab}$ \\
\hline ST05 & $24.47 \pm 1.73 \mathrm{ab}$ & $52.24 \pm 1.96 \mathrm{abc}$ & $76.30 \pm 2.91 \mathrm{a}$ & $67.47 \pm 2.03 \mathrm{a}$ & $74.17 \pm 5.36 \mathrm{a}$ & $97.45 \pm 1.95 \mathrm{a}$ & $98.44 \pm 1.02 \mathrm{a}$ \\
\hline -value & .000046 & .000174 & .000001 & .000001 & .000010 & .000012 & .003090
\end{tabular}

Note: Lowercase letters in the column mean statistical difference $(p<.05)$. 
harveyi, Vibrio anguillarum and V. alginolyticus. For Lactobacillus plantarum, in this study, its inhibitory ability was mainly observed against Vibrio parahaemolyticus, showing the same results with the antibiotic oxytetracycline. This ability could be explained by the production of lactic acid, hydrogen peroxide and plantaricin (Hernandez, Cardell, \& Zarate, 2005; Sugita, Ohta, Kuruma, \& Sagesaka, 2007). According to Klaenhammer (1993), this specific component 'plantaricine' acts as powerful bactericide against gram-negative bacteria. Thus, Lactobacillus plantarum may be an efficient probiotic for aquaculture. This is the first report of the autochthonous probiotic for clownfish Amphiprion ocellaris recommending L. plantarum as a potential probiotic.

\section{ACKNOWLEDGEMENTS}

The authors thank to National Council for Scientific and Technology development (CNPq) for financial support to R.Y. Fujimoto (305195/2016-6), M.L. Martins (CNPq 306635/2018-6), J.L.P. Mouriño (CNPq 301524/2017-3) and CAPES/FAPITEC (12/2016) for MSc scholarship to P.E.G. Paixão.

\section{CONFLICTS OF INTEREST}

The authors have no conflicts of interest to declare.

\section{DATA AVAILABILITY STATEMENT}

The data that support the findings of this study are available from the corresponding author upon reasonable request.

\section{ORCID}

Peterson Emmanuel Guimarães Paixão (iD https://orcid. org/0000-0002-8949-4232

Higo Andrade Abe iD https://orcid.org/0000-0002-5717-9641

\section{REFERENCES}

Balcázar, J. L., De Blas, I., Ruiz-Zarzuela, I., Cunningham, D., Vendrell, D., \& Muzquiz, J. L. (2006). The role of probiotics in aquaculture. Veterinary Microbiology, 114(3-4), 173-186. https://doi.org/10.1016/j. vetmic.2006.01.009

Baldisserotto, B., Mancera Romero, J. M., \& Kapoor, B. G. (2007). Fish osmoregulation (pp. 333-359). Boca Raton, FL: CRC Press, Taylor \& Francis Group.

Bolívar Ramírez, N. C., Rodrigues, M. S., Guimarães, A. M., Guertler, C., Rosa, J. R., Seiffert, W. Q., ... Vieira, F. D. N. (2017). Effect of dietary supplementation with butyrate and probiotic on the survival of Pacific white shrimp after challenge with Vibrio alginolyticus. Revista Brasileira De Zootecnia, 46(6), 471-477. https://doi.org/10.1590/ s1806-92902017000600001

Cornélio, F. H. G., Cargnin-Ferreira, E., Borba, M. R. D., Mouriño, J. L. P., Fernandes, V. A. G., \& Fracalossi, D. M. (2013). Growth, digestibility and resistance to pathogen infection in Nile tilapia fed with probiotics. Pesquisa Agropecuaria Brasileira, 48(8), 863-870.

Dias, J. A., Abe, H. A., Sousa, N. C., Couto, M. V., Cordeiro, C. A., Meneses, J. O., ... Fujimoto, R. Y. (2018). Dietary supplementation with autochthonous Bacillus cereus improves growth performance and survival in tambaqui Colossoma macropomum. Aquaculture Research, 49(9), 3063-3070.

FAO. (2017). Food and Agriculture Organization of the United Nations, Aquaculture Newsletter (pp. 38-39). Rome, Italy: FAO. Retrieved from http://www.fao.org/3/a-i7171e.pdf 
Hernandez, D., Cardell, E., \& Zarate, V. (2005). Antimicrobial activity of lactic acid bacteria isolated from Tenerife cheese: Initial characterization of plantaricin TF711, a bacteriocin-like substance produced by Lactobacillus plantarum TF711. Journal of Applied Microbiology, 99(1), 77-84.

Jatobá, A., Pereira, M. O., Vieira, L. M., Bitencourt, M., Rodrigues, E., Fachini, F. A., \& Moraes, A. V. (2018). Action time and feed frequency of Lactobacillus plantarum for Nile tilapia. Arquivo Brasileiro De Medicina Veterinária E Zootecnia, 70(1), 327-332. https://doi. org/10.1590/1678-4162-9870

Lambert, J. M., Bongers, R. S., de Vos, W. M., \& Kleerebezem, M. (2008). Functional analysis of four bile salt hydrolase and penicillin acylase family members in Lactobacillus plantarum WCFS1. Applied and Environmental Microbiology, 74(15), 4719-4726.

Nandi, A., Dan, S. K., Banerjee, G., Ghosh, P., Ghosh, K., Ringø, E., \& Ray, A. K. (2017). Probiotic potential of autochthonous bacteria isolated from the gastrointestinal tract of four freshwater teleosts. Probiotics and Antimicrobial Proteins, 9(1), 12-21. https://doi.org/10.1007/ s12602-016-9228-8

Pavanelli, G. C., Eiras, J. C., \& Takemoto, R. M. (2008). Doenças de Peixes: Profilaxia, diagnóstico e tratamento. Maringá, Brazil: Eduem.

Pramod, P. K., Sajeevan, T. P., Ramachandran, A., Thampy, S., \& Pai, S. S. (2010). Effects of two anesthetics on water quality during simulated transport of a tropical ornamental fish, the Indian tiger barb Puntius filamentosus. North American Journal of Aquaculture, 72(4), 290-297.

Ricciardi, A., Parente, E., \& Zotta, T. (2009). Modelling the growth of Weissella cibaria as a function of fermentation conditions. Journal of Applied Microbiology, 107(5), 1528-1535.

Sayes, C., Leyton, Y., \& Riquelme, C. (2018). Probiotic Bacteria as a Healthy Alternative for Fish Aquaculture. In S. Savic (Eds.), Antibiotic use in animals. Rijeka, Croatia: InTech.

Son, S. H., Jeon, H. L., Jeon, E. B., Lee, N. K., Park, Y. S., Kang, D. K., \& Paik, H. D. (2017). Potential probiotic Lactobacillus plantarum Ln4 from kimchi: Evaluation of $\beta$-galactosidase and antioxidant activities. LWT-Food Science and Technology, 85, 181-186. https://doi. org/10.1016/j.Iwt.2017.07.018

Succi, M., Tremonte, P., Reale, A., Sorrentino, E., Grazia, L., Pacifico, S., \& Coppola, R. (2005). Bile salt and acid tolerance of Lactobacillus rhamnosus strains isolated from parmigiano reggiano cheese. FEMS Microbiology Letters, 244(1), 129-137.
Sugita, H., Ohta, K., Kuruma, A., \& Sagesaka, T. (2007). An antibacterial effect of Lactococcus lactis isolated from the intestinal tract of the Amur catfish, Silurus Asotus Linnaeus. Aquaculture Research, 38(9), 1002-1004. https://doi.org/10.1111/j.1365-2109.2007.01765.x

Tekippe, E. M., Shuey, S., Winkler, D. W., Butler, M. A., \& Burnham, C. A. D. (2013). Optimizing identification of clinically relevant gram-positive organisms using the Bruker Biotyper MALDI-TOF MS system. Journal of Clinical Microbiology, 51, 1421-1427.

Van Doan, H., Doolgindachbaporn, S., \& Suksri, A. (2016). Effect of Lactobacillus plantarum and Jerusalem artichoke (Helianthus tuberosus) on growth performance, immunity and disease resistance of Pangasius catfish (Pangasius bocourti, Sauvage 1880). Aquaculture Nutrition, 22(2), 444-456.

Vieira, F. D. N., Jatobá, A., Mouriño, J. L. P., Vieira, E. A., Soares, M., Silva, B. C. D., ... Vinatea, L. A. (2013). In vitro selection of bacteria with potential for use as probiotics in marine shrimp culture. Pesquisa Agropecuária Brasileira, 48(8), 998-1004. https://doi.org/10.1590/ S0100-204X2013000800027

Vine, N. G., Leukes, W. D., Kaiser, H., Daya, S., Baxter, J., \& Hecht, T. (2004). Competition for attachment of aquaculture candidate probiotic and pathogenic bacteria on fish intestinal mucus. Journal of Fish Diseases, 27(6), 319-326.

Wesseling, W., Wittka, S., Kroll, S., Soltmann, C., Kegler, P., Kunzmann, A., ... Lohmeyer, M. (2015). Functionalised ceramic spawning tiles with probiotic Pseudoalteromonas biofilms designed for clownfish. Aquaculture, 446, 57-66. https://doi.org/10.1016/j.aquaculture. 2015.04.017

Whittamore, J. M. (2012). Osmoregulation and epithelial water transport: Lessons from the intestine of marine teleost fish. Journal of Comparative Physiology B, 182(1), 1-39. https://doi.org/10.1007/ s00360-011-0601-3

\section{How to cite this article: Paixão PEG, Couto MVS, Costa}

Sousa $\mathrm{N}$, et al. In vitro selection of autochthonous lactic acid bacterium from clownfish Amphiprion ocellaris. Aquac Res. 2019;00:1-4. https://doi.org/10.1111/are.14396 